\title{
Innovative approach to evaluating the correlation between the distribution of the concentration of enzymes in the blood serum and heart tissues of rats
}

\author{
Pavel Boriskin ${ }^{1}$, Olga Gulenko ${ }^{2}$, Anatoliy Deviatkin ${ }^{1}$, Victor Leonov ${ }^{2}$, Olga Pavlova, ${ }^{3, *}$ \\ ${ }^{1}$ Kazan State Academy of Veterinary Medicine named after N.E. Bauman, st. Siberian tract, 35, \\ Kazan, 420074, Republic of Tatarstan, Russia \\ ${ }^{2}$ Private institution educational organization of higher education "Medical University "Reaviz", \\ st.Chapaevskaya, 227, Samara, 443099, Russia \\ ${ }^{3}$ LLC «TestGen», 44th passage Engineering, 9, office 13, Ulyanovsk, 432072, Russia
}

\begin{abstract}
Cardiovascular diseases (CVDs) have been the leading cause of death worldwide for many years. In recent years, new CVD markers have been sought that can improve the diagnosis and treatment of this broad and predictably unfavorable group of diseases. The efforts of many researchers are aimed at identifying changes in the level of enzymes in the lipid peroxidation system as possible mechanisms underlying the development of CVDs. The imbalance between the intensification of free-radical oxidation caused by active oxygen forms and the activity of the body's protective antioxidant system leads to serious disturbances: disorganization of cellular structures, changes in their functional activity. The article presents the study of the interrelations between the concentration distribution of POL-AO enzymes in blood serum and heart tissues of white non-pedigree rats. The correlation coefficients of Spearman, the gamma of correlation and Kendel Tau revealed a reliable presence of weak correlation between the concentration of glutathione peroxidase in blood serum and heart tissues (Spearman $\mathrm{R}=0.18$ at $\mathrm{p} \leq 0.029408$, Gamma $=$ 0.14 at $\mathrm{p} \leq 0.018701 ;$ Kendall Tau $=0.13$ at $\mathrm{p} \leq 0.018701$ ).
\end{abstract}

\section{Introduction}

The highest prevalence of cardiovascular disease (CVD) is responsible for increasing mortality and disability among the working population in economically developed countries. The search for the root causes of etymology of various diseases leads to the concept of oxidative stress, which develops against the background of homeostatic imbalance of the body under the influence of endo- and exogenous factors.

The formation of oxygen radicals in the cardiovascular system is initiated by a number of cytoplasmic enzymes - xanthine oxidase, separated forms of NO-synthase (NOS), membrane-oriented complexes of enzymes - cytochrome P-450 isoforms, phagocyte

\footnotetext{
*Corresponding author: casiopeya13@mail.ru
} 
enzymatic complex, as well as I and III complexes of the respiratory chain of mitochondria. The active forms of oxygen (AFC) include free radicals (FR) - molecules with one or more non-sticky electrons on atomic or molecular orbitals - superoxide anion radical, hydroxyl radical, lipid radical. Hydrogen peroxide, peroxynitrite, hypochloric acid $(\mathrm{HOCl})$, although not SR, also belong to the group of ROS, but their oxidative effects are promoted by ROS. Manufacture of one type of SR starts a cascade of radicals synthesis by means of chain reactions [1]. At the same time, the release of ROS beyond the limits of physiological norms leads to the development of oxidative stress - the terminology was introduced in 1991 by Helmut Zisom [2]. The main suppliers of ROS in heart tissues are NADPHoxidase concentrated in blood phagocytes, tissue macrophages, mitochondria of oxygendependent cardiomyocyotes, the latter being the main consumers of molecular oxygen for redox ATP synthesis reactions. The transport of electrons in the respiratory chain of mitochondria generates energy to transport protons through the internal membrane from the matrix to the intermembrane space. As a result, the difference in electro potential and $\mathrm{pH}$ gradient necessary for proton transport in mitochondria and ATP synthesis is formed. The formation of superoxide radical anion normally consumes $0.5-1.5 \%$ of oxygen, and in general, the synthesis of AFK can be spent from 10 to $30 \%$ of the oxygen absorbed by the body. Superoxide anion radical acts as a secondary messenger influencing the radicalsensitive enzymatic signaling systems involved in the physiological activity of cells $[3,4]$. Accordingly, oxidative stress and free radicals in low concentrations are elements of the adaptation mechanism, affecting vascular tone and immune response of the body [5].

Intensification of redox processes enhances the formation of ROS such as peroxynitrite, superoxide anion and others, provokes vascular endothelial dysfunction, depriving it of the ability to adapt to changes in hemodynamics, increasing vasoconstriction, which in turn leads to the development of a number of diseases: hypertension, renovascular and malignant arterial hypertension, dyslipidemia, thrombosis, metabolic syndrome, diabetic and dilatational cardiomyopathy, atherosclerosis, ischemic heart disease, arterial hypertension (AG), diabetes mellitus $[6,7,8,9,10]$. One of the frequent variants of CVD development is the formation of chronic heart failure, and the more risk factors for this pathology are identified, the more intensive the oxidation processes in the body [11]. Free radicals cause damage to cardiomyocytes, disrupt the structural modification of the lipid layer with subsequent remodeling of the myocardium, thereby impairing its contractile functions, causing a direct negative inotropic effect, and also disrupt the structure of mitochondrial DNA, reducing their activity [12] and leading to cell death $[13,14,15,16$, $17,18]$.

Despite the rather deep study of cardiovascular system pathologies, the data on the functional activity of myocardial cells under destructive effects and oxidative stress are still insufficient.

Thus, the aim of our study was to study the relationship between the distribution of POL-AO enzyme concentrations in blood serum and heart tissues of white non-pedigree rats.

To achieve this goal, the following tasks had to be performed: to determine the concentration of catalase, superoxide dismutase (SOD), glutathione peroxidase (GP), glutathione reductase (GR), malonedialdehyde (MDA) and diene conjugates (DC) in blood serum and heart tissues of white non-pedigreed rats; to reveal the relationship between the concentration distribution of enzymes of the POL-AO system in blood serum and heart tissues of rats.

\section{Materials and methods}


The study was carried out on white, non-patented, healthy male rats of the same month of birth, weighing 180-200 g, in the amount of 150 pieces, which were kept in the vivarium under standard conditions.

The research was carried out in accordance with the rules of laboratory practice in the Russian Federation: the order of the Ministry of Health of the USSR № 755 from 12.08.1977, the order of the Ministry of Health of the Russian Federation № 267 from 19.06.2003, the law "On the protection of animals from cruelty", Chapter V, Art. 104679GD from 01.12.1999.

Determination of catalase activity was carried out using the standard method of Korolyuk M.A. The activity of superoxide dismutase was determined by the method of V.S. Gurevich and co-authors. The activity of glutathione peroxidase was determined by the method of V.M. Moyn. The activity of glutathione reductase and diene conjugates was determined spectrophotometrically at a wavelength of $340 \mathrm{~nm}$ and $233 \mathrm{~nm}$, respectively. The MDA concentration was determined by the V.V. method. Bogozhin [19].

Enzyme concentrations were studied in heart tissue and blood serum. For this purpose, rats were ethically murdered under etheric anesthesia by decapitation, and then the necessary tissues were extracted, which (except for blood serum) were washed with physiological solution and immediately frozen. Homogenates were prepared by mechanical shredding of tissues weighing $1 \mathrm{~g}$ with $9 \mathrm{ml}$ of tris buffer $(\mathrm{pH} \mathrm{7.4)}$ ), at a rate of $5000 \mathrm{rpm}$ in a vessel with double walls, constantly cooled by running water. [19].

Digital material was statistically processed by nonparametric Spearman correlation analysis, as well as by using gamma correlation coefficients and Kendella Tau.

\section{Results of the study}

As a result of experiments, an array of numerical concentrations of catalase, SOD, GP, GR, MDA and diene conjugates to blood serum and heart tissues of white non-pedigreed rats was obtained. The obtained results were statistically processed (Table 1). At the first stage of the statistical analysis, we tested for compliance with the normal distribution of POL-AO enzyme concentrations in blood serum and heart tissues of rats. For this purpose Kolmogorov-Smirnov single-sample criterion was used. As a result, it was found that the distribution of POL-AO system enzymes concentration in blood serum and heart tissues of rats does not correspond to normal. In connection with that at the further statistical processing we applied nonparametric methods of analysis.

Table1. Distribution of POL-AO enzyme concentrations in blood serum and heart tissues of white rats

\begin{tabular}{|l|c|c|c|c|c|c|c|c|c|}
\hline $\begin{array}{c}\text { Descriptive } \\
\text { statistics of } \\
\text { merged } \\
\text { groups }\end{array}$ & $\mathrm{N}$ & $\mathrm{M}$ & $\mathrm{Me}$ & Min & Max & $\begin{array}{c}25 \\
\text { Perc }\end{array}$ & $\begin{array}{c}75 \\
\text { Perc }\end{array}$ & $\begin{array}{c}10 \\
\text { Perc }\end{array}$ & $\begin{array}{c}90 \\
\text { Perc }\end{array}$ \\
\hline \multicolumn{8}{|c|}{ Catalase } \\
\hline $\begin{array}{l}\text { Bloodseru } \\
\text { m }\end{array}$ & $\begin{array}{c}15 \\
0\end{array}$ & 19,72 & $\mathbf{1 9 , 6 0}$ & 17,40 & 22,10 & $\mathbf{1 8 , 9 0}$ & $\mathbf{2 0 , 4 0}$ & 18,35 & 21,40 \\
\hline Heart & $\begin{array}{c}15 \\
0\end{array}$ & 29,25 & $\mathbf{2 9 , 4 0}$ & 27,10 & 30,90 & $\mathbf{2 8 , 5 0}$ & $\mathbf{3 0 , 1 0}$ & 28,10 & 30,60 \\
\hline \multicolumn{8}{|c|}{ Superoxidedismutase } \\
\hline Bloodseru & 15 & 29,01 & $\mathbf{2 9 , 1 0}$ & 27,30 & 30,70 & $\mathbf{2 8 , 4 0}$ & $\mathbf{2 9 , 6 0}$ & 28,00 & 30,20 \\
\hline
\end{tabular}




\begin{tabular}{|c|c|c|c|c|c|c|c|c|c|}
\hline $\mathrm{m}$ & 0 & & & & & & & & \\
\hline Heart & $\begin{array}{c}15 \\
0\end{array}$ & 96,96 & 96,80 & 94,80 & 98,90 & 96,30 & 97,70 & 95,60 & 98,45 \\
\hline \multicolumn{10}{|c|}{ Glutathioneperoxidase } \\
\hline Bloodseru & 15 & 123,5 & 123,5 & 122,1 & 125,1 & 123,1 & 124,2 & 122,6 & 124,7 \\
\hline & 0 & 0 & $\mathbf{0}$ & 0 & 0 & $\mathbf{0}$ & $\mathbf{0}$ & 0 & \\
\hline Heart & $\begin{array}{c}15 \\
0\end{array}$ & $\begin{array}{c}272,0 \\
4\end{array}$ & $\begin{array}{c}271,9 \\
0\end{array}$ & $\begin{array}{c}270,7 \\
0\end{array}$ & $\begin{array}{c}273,8 \\
0\end{array}$ & $\begin{array}{c}271,5 \\
0\end{array}$ & $\begin{array}{c}272,6 \\
0\end{array}$ & $\begin{array}{c}271,2 \\
5\end{array}$ & $\begin{array}{c}273,1 \\
0\end{array}$ \\
\hline \multicolumn{10}{|c|}{ Glutathionereductase } \\
\hline $\begin{array}{l}\text { Bloodseru } \\
\mathrm{m}\end{array}$ & $\begin{array}{c}15 \\
0\end{array}$ & 70,75 & $\mathbf{7 0 , 8 0}$ & 69,40 & 71,80 & 70,40 & 71,20 & 69,80 & 71,60 \\
\hline Heart & $\begin{array}{c}15 \\
0\end{array}$ & 53,44 & 53,40 & 52,10 & 54,90 & 53,10 & 53,80 & 52,60 & 54,30 \\
\hline \multicolumn{10}{|c|}{ MaloneDialdehyde } \\
\hline $\begin{array}{l}\text { Bloodseru } \\
\mathrm{m}\end{array}$ & $\begin{array}{c}15 \\
0\end{array}$ & 6,31 & 6,35 & 5,30 & 7,90 & 5,90 & 6,70 & 5,70 & 6,90 \\
\hline Heart & $\begin{array}{c}15 \\
0\end{array}$ & 6,58 & 6,60 & 5,40 & 7,50 & 6,20 & 6,90 & 5,85 & 7,20 \\
\hline \multicolumn{10}{|c|}{ Dieneconjugates } \\
\hline $\begin{array}{l}\text { Bloodseru } \\
\mathrm{m}\end{array}$ & $\begin{array}{c}15 \\
0\end{array}$ & 34,31 & 34,30 & 32,90 & 35,60 & 33,90 & 34,70 & 33,50 & 35,10 \\
\hline Heart & $\begin{array}{c}15 \\
0\end{array}$ & 58,24 & 58,30 & 57,10 & 59,80 & 57,60 & $\mathbf{5 8 , 7 0}$ & 57,30 & 59,20 \\
\hline
\end{tabular}

In order to estimate the correlation between the concentration distribution of POL-AO enzymes in blood serum and heart tissues of small experimental animals, we studied the correlations within the observation group using the nonparametric Spearman correlation coefficient (Table 2), as well as using the gamma correlation coefficients and Kendella Tau (Table 3).

Table 2.Spearman correlation coefficient for the distribution of POL-AO enzyme concentration in blood serum and rat heart tissues and $\mathrm{p}$

\begin{tabular}{|l|l|c|c|c|}
\hline \multicolumn{1}{|c|}{ Enzyme } & $\begin{array}{c}\text { Spearman correlation } \\
\text { in all combined } \\
\text { dimensions }\end{array}$ & ValidN & SpearmanR & p-level \\
\hline Catalase & Bloodserum\&heart & 150 & $-0,072130$ & 0,380397 \\
\hline Superoxidedismutase & Bloodserum\&heart & 150 & $-0,079408$ & 0,334076 \\
\hline Glutathioperoxidase & Bloodserum\&heart & $\mathbf{1 5 0}$ & $\mathbf{0 , 1 7 7 8 9 8}$ & $\mathbf{0 , 0 2 9 4 0 8}$ \\
\hline Glutathionereductase & Bloodserum\&heart & 150 & 0,059254 & 0,471360 \\
\hline MaloneDialdehyde & Bloodserum\&heart & 150 & 0,113406 & 0,167040 \\
\hline Dieneconjugates & Bloodserum\&heart & 150 & 0,119623 & 0,144822 \\
\hline
\end{tabular}

According to the data presented in Table 2, a weak correlation between glutathione peroxidase concentration in blood serum and heart tissues $(0.18$ at $\mathrm{p} \leq 0.029408)$ can be traced.

Since no correlation was found between the distribution of POL-AO enzyme concentrations in blood serum and rat heart tissues using the Spearman correlation coefficient, it was 
decided to perform an analysis using the gamma correlation criteria and Kendella Tau (Table 3).

Table 3.Gamma and Kendella Tau correlation coefficients for POL-AO enzyme concentration distribution in blood serum and rat heart tissues

\begin{tabular}{|c|c|c|c|c|c|}
\hline \multicolumn{6}{|c|}{ CorrelationGammaRatioCoefficient } \\
\hline \multicolumn{6}{|c|}{ MD pairwise deleted Marked correlations are significant at $p<0,05000$} \\
\hline Enzyme & $\begin{array}{c}\text { Correlation in all } \\
\text { combined } \\
\text { measurements }\end{array}$ & $\begin{array}{c}\text { Valid } \\
\mathbf{N}\end{array}$ & Gamma & $\mathbf{Z}$ & p-level \\
\hline Catalase & Bloodserum\&heart & 150 & $-0,050561$ & $-0,88672$ & 0,375229 \\
\hline Superoxidedismutase & Bloodse & 150 & $-0,056349$ & $\begin{array}{c}- \\
0,985468\end{array}$ & 0,324394 \\
\hline Glutathioperoxidase & Bloodserum\&heart & 150 & $\mathbf{0 , 1 3 6 0 0 9}$ & 2,351434 & $\mathbf{0 , 0 1 8 7 0 1}$ \\
\hline Glutathionereductase & Bloodserum\&heart & 150 & 0,045872 & 0,780006 & 0,435388 \\
\hline MaloneDialdehyde & Bloodserum\&heart & 150 & 0,083248 & 1,412586 & 0,157778 \\
\hline Dienecon & Bloodserum\&heart & 150 & 0,086370 & 1,48474 & 0,137613 \\
\hline \multicolumn{6}{|c|}{ KendallTau'scorrelationcoefficient } \\
\hline \multicolumn{6}{|c|}{ MD pairwise deleted Marked correlations are significant at $\mathrm{p}<, 05000$} \\
\hline Enzyme & $\begin{array}{c}\text { Correlation in all } \\
\text { combined } \\
\text { measurements }\end{array}$ & $\begin{array}{c}\text { Valid } \\
\mathrm{N}\end{array}$ & KendallTau & $\mathrm{Z}$ & p-level \\
\hline Catalase & Bloodserum\&heart & 150 & $-0,048831$ & $-0,88672$ & 0,375229 \\
\hline Superoxidedismutase & Bloodse & 150 & $-0,054268$ & $\begin{array}{c}- \\
0,985468\end{array}$ & 0,324394 \\
\hline Glutathioperoxidase & Bloodserum\&heart & 150 & 0,129490 & 2,351434 & 0,018701 \\
\hline Glutathionereductase & Bloodserum\&heart & 150 & 0,042954 & 0,780006 & 0,435388 \\
\hline MaloneDialdehyde & Bloodserum\&heart & 150 & 0,077789 & 1,412586 & 0,157778 \\
\hline Dieneconjugates & Bloodserum\&heart & 150 & 0,081763 & 1,48474 & 0,137613 \\
\hline
\end{tabular}

According to the data presented in Table 3 it is evident that in the study of the distribution of concentrations of enzymes of the POL-AO system in blood serum and heart tissues of rats the direct reliable correlation of weak force between the concentration of glutathione peroxidase in blood serum and heart tissues of white non-pedigreed rats was revealed: Gamma 0.14 at $\mathrm{p} \leq 0.018701$; Kendall Tau 0.13 at $\mathrm{p} \leq 0.018701$.

\section{Conclusions}

Thus, all three methods of nonparametric correlation analysis used to assess the relationship between the concentration distribution of enzymes of the POL-AO system in blood serum and heart tissues of rats, which in the activity of glutathione peroxidase in rats within the 
physiological norm is determined by a direct reliable correlation between the weak force concentration of glutathione peroxidase in blood serum and heart tissues.

\section{References}

1. L.O. Palatkina, O.N. Korneeva, O.M. Drapkina, Cardiovascular Therapy and Prevention, 11(6), 1-94 (2012)

2. E.I. Astashkin, M.G. Glezer, Medical Council, 10, 104-110 (2016)

3. O.A. Grebenchikov, T.S. Zabelina, Messenger of Anesthesiologyand Resuscitation, 13(4), 53-60 (2016)

4. E.I. Astashkin, M.G. Glezer, Cardiology and cardiovascular surgery, 6(2), 58-65 (2012)

5. S.A. Rumyantseva et, Actual issues of neurologists, 3, 8-12 (2009)

6. M.Y. Martynov, A.N. Yasamanova, T.I. Kolesnikova, etc, ConsiliumMedicum. Neurology, 2, 14-17

7. O. Pavlova, S. Simakova, Ulyanovsk: USU, 244-246 (2011)

8. J. Xu, F. Lupu, C. Esmon, Hamostaseol, 1, 30, 5-9 (2010)

9. A. Iyer, D. Fairlie, J. Prins, et, Nature Rev Endocrin, 2, 6, 71-82 (2010)

10. H. Buggerand, D. Abel, Cardiovascular Research, 2, 88, 229-40 (2010)

11. G.S. Shadel, S. Ghosh, Nat. Rev. Immunol, 11, 389-402 (2011)

12. M. Mittal, M.R. Siddiqui, K. Tran, S.P. Reddy, A.B. Malik, Antioxid. Redox Signal, 20, 1126-1167 (2014)

13. J.A. Chirinos, S.R. Akers, et, J Am Heart Assoc., 5 (10), 1-8 (2016)

14. Y.N. Belenkov, E.V. Privalova, Y.A. Danilogorskaya, etc., Cardiol heart.-vessel chir.,1, 4-9 (2009)

15. L.O. Tentina, O.N. Korneeva, O.M. Drapkina, Cardiovascular Therapy and Prevention., 11(6), 91-94 (2012)

16. P. Horn, M.M. Cortese-Krott, A. Nicolas, et, J. Am. Heart Assoc., 2(1), e003764 (2012)

17. H.J. Hsieh, C.A. Liu, B. Huang, A.H. Tseng, D.L.Wang, J Biomed Sci., 21(1), 3 doi: 10.1186/1423-0127-21-3

18. A.I. Khaletskaya, A.N. Kuznetsov, K.N. Kontorschikova, D.A. Leonova, Medical Almanac., 5, 225-230 (2018)

19. D.I. Maksimovich, E.O. Korik, Internauka, 12-1 (16), 10-12 